\title{
Tuberculosis/HIV coinfection from the perspective of quality of life: scope review
}

\author{
A coinfecção tuberculose/HIV na perspectiva da qualidade de vida: revisão de escopo \\ La coinfección tuberculosis/VIH en la perspectiva de calidad de vida: revisión sistemática
}

Marcos Vinícius de Freitas Carvalho' ORCID: 0000-0003-4633-413X

Mônica Taminato'

ORCID: 0000-0003-4075-2496

Maria Rita Bertolozzi"

ORCID: 0000-0002-5009-5285

Lúcia Yasuko Izumi Nichiata"

ORCID: 0000-0001-6515-4404

Hugo Fernandes'

ORCID: 0000-0003-2380-2914

Paula Hino'

ORCID: 0000-0002-1408-196X

'Universidade Federal de São Paulo. São Paulo, São Paulo, Brazil. "Universidade de São Paulo. São Paulo, São Paulo, Brazil.

How to cite this article:

Carvalho MVF, Taminato M, Bertolozzi MR, Nichiata LYI, Fernandes $\mathrm{H}$, Hino P. Tuberculosis/HIV coinfection from the perspective of quality of life: scope review.

Rev Bras Enferm. 2021;74(3):e20200758

https://doi.org/10.1590/0034-7167-2020-0758

\section{Corresponding author:}

Marcos Vinícius de Freitas Carvalho

E-mail: mvcarvalho.carvalho@gmail.com

EDITOR IN CHIEF: Antonio José de Almeida Filho ASSOCIATE EDITOR: Fátima Helena Espírito Santo

Submission: 08-03-2020

Approval: 01-19-2021

\section{ABSTRACT}

Objectives: to analyze evidence on the quality of life of people with tuberculosis/HIV coinfection. Methods: review that followed steps of the Cochrane Collaboration, with the search of publications in the bases Embase, LILACS, PubMed, and Cochrane, through the descriptors "HIV," "Tuberculosis," and "Quality of Life," without a temporal cut. Results: the results include 15 studies, published between 2009 and 2019, with the level of evidence V, in its majority. It was observed that there is no uniformity in the instrument used. Psychological support to this group and strengthening of actions to manage both infections are necessary. This segment's quality of life is associated with social factors and scientific production on the subject concentrated in underdeveloped countries. Conclusions: the articles found have a low level of scientific evidence and indicate that people who experience coinfection have a more compromised quality of life when compared to those who experience tuberculosis or HIV separately.

Descriptors: Tuberculosis; HIV; Quality of Life; Public Health; Community Health Nursing.

\section{RESUMO}

Objetivos: mapear e analisar as evidências sobre a qualidade de vida de pessoas que apresentam a coinfecção tuberculose/HIV. Métodos: revisão de escopo que seguiu as etapas propostas pela Colaboração Cochrane, com busca de publicações nas seguintes bases de dados: Embase, LILACS, PubMed e Cochrane, por meio dos descritores "HIV", "Tuberculosis", e "Quality of Life", sem recorte temporal. Resultados: foram incluídos 15 estudos, publicados entre 2009 e 2019, na língua inglesa e, em sua maioria, com nível de evidência V. Observouse que não há uniformização no instrumento utilizado para avaliar a qualidade de vida em participantes com coinfecção tuberculose/HIV. É necessário suporte psicológico a esse grupo e fortalecimento de ações para prevenção e manejo de ambas as infecções. A qualidade de vida desse segmento populacional está intimamente associada a fatores sociais, sendo que a produção científica sobre o tema se concentra em países subdesenvolvidos ou em desenvolvimento. Conclusões: os artigos encontrados possuem baixo nível de evidência científica, e indicam que as pessoas que vivenciam a coinfecção apresentam qualidade de vida mais comprometida quando comparadas àquelas que vivenciam a tuberculose ou o HIV como agravos únicos.

Descritores: Tuberculose; HIV; Qualidade de Vida; Saúde Pública; Enfermagem em Saúde Comunitária.

\section{RESUMEN}

Objetivos: mapear y analizar las evidencias sobre calidad de vida de personas que presentan la coinfección tuberculosis/VIH. Métodos: revisión sistemática que siguió las etapas propuestas por la Colaboración Cochrane, con búsqueda de publicaciones en las siguientes bases de datos: Embase, LILACS, PubMed y Cochrane, por medio de los descriptores "VIH", "Tuberculosis", y "Quality of Life", sin recorte temporal. Resultados: fueron incluidos 15 estudios, publicados entre 2009 y 2019, en lengua inglesa y, en su mayoría, con nivel de evidencia V. Observó que no hay estandarización en el instrumento utilizado para evaluar la calidad de vida de los participantes. Conclusiones: los artículos encontrados poseen bajo nivel de evidencia científica, e indican que las personas que experimentan la coinfección presentan la calidad de vida más comprometida cuando comparadas a aquellas que experimentan la tuberculosis o el VIH como agravios únicos.

Descriptores: Tuberculosis; VIH; Calidad de Vida; Salud Pública; Enfermería en Salud Comunitaria. 


\section{INTRODUCTION}

Tuberculosis (TB) represents a severe public health issue, one of the first causes of death worldwide and the main one for a single infectious agent. The World Health Organization (WHO) has estimated that in 2019 approximately 10 million people became ill with TB and 1.4 million deaths occurred due to the disease ${ }^{(1)}$.

When associated with the human immunodeficiency virus (HIV) infection, TB can potentiate the clinical and epidemiological picture of this condition. Although the WHO recommends the anti-HIV test for every person diagnosed with TB, the latest data available for 2019 showed that, worldwide, $69 \%$ of reported cases performed HIV serology, and $9.5 \%$ the percentage of TB/HIV coinfection ${ }^{(1)}$.

In 2019, Brazil notified 73,864 new TB cases (incidence coefficient of 35 cases $/ 100$ thousand inhabitants), and $8.4 \%$ presented TB/HIV coinfection. There was an increase in HIV testing in people with TB, from $62.1 \%$ in 2010 to $76.1 \%$ in 2019 . In the same year, antiretroviral therapy (ART) performance among new cases of TB with coinfection was $47.5 \%{ }^{(2)}$.

There is a divergence between international and Brazilian data, because in the world, although HIV testing in confirmed cases of TB has been lower (69\%), the percentage of coinfection (9.5\%) was higher if compared to Brazil (8.4\%), where testing presented a higher percentage (76.1\%). There are no data in the literature that justify such a difference. Brazilian health policies could explain this, and the clinical management of HIV cases should prevent TB from developing.

The expedient diagnosis of TB and HIV enables the early initiation of the respective treatments ${ }^{(3)}$. With the introduction of the policy of universal and free access to ART, since 1996, advances have been observed in the control of acquired immunodeficiency syndrome (AIDS), with an impact on morbidity and mortality rates, decrease in hospitalizations, and improvement in the quality of life (QoL) of infected people(4).

The number of drugs added to the overlap of side effects and drug interactions can have repercussions on $\mathrm{QoL}$ and adherence to treatment of people living with TB/HIV coinfection ${ }^{(3)}$.

According to WHO definition ${ }^{(5)}$, QoL involves the individual's perception and the social environment in which they live. The Organization recognizes that it is a broad concept that "incorporates in a complex way the physical health, psychological state, level of independence and social relations of people, as well as their interfaces with important characteristics of their environment".

Participants of a study conducted in Rio de Janeiro characterized TB/HIV coinfection as a challenging experience, which brought tremendous suffering to life and consequently affected QoL. As potentials for strengthening/coping supporting networks, patients considered family, religion, and healthcare services ${ }^{(4)}$.

As HIV/AIDS infection, TB is a disease marked by stigma and prejudice. The acceptance of the new health status is a complicated process, mainly when referring to HIV/AIDS, often understood as the cause of TB. Therefore, the person who experiences TB/HIV coinfection faces not only physical consequences but also stressful situations at the emotional and social levels, which may cause anxieties and internal conflicts that directly affect QoL ${ }^{(4,6-8)}$.

The previous consultation of the databases used in this review has shown that there is a wide range of studies on QoL of people with TB, or PLHIV (people living with HIV/AIDS), but the same does not occur with the approach of the same theme in people with TB/HIV coinfection. By gathering the studies already done on the subject and filling the gap of knowledge, this study presents a guiding question: What is the scientific evidence on QoL of people with TB/HIV coinfection?

It is based on the assumption that the knowledge of the aspects that interfere in QoL makes it possible to rethink the health practices directed to this population group's care, including through the elaboration or improvement of specific public policies.

\section{OBJECTIVES}

To map and analyze the evidence of QoL in people who have TB/HIV coinfection.

\section{METHODS}

Scope review following the recommendations proposed by Joanna Briggs Methods ${ }^{(9)}$ and PRISMA-SScR (Preferred Reporting Items for Systematic Reviews and Meta-Analyses Extension for Scoping Reviews) ${ }^{(10)}$. The PICO ${ }^{(11)}$ strategy, an acronym for Patient, Intervention, Comparison, and Outcomes, was used to design the research question: $\mathrm{P}$ - People experiencing TB/HIV coinfection; I - Not applicable; C - No intervention; and O - QoL.

The inclusion criteria were: articles addressing specifically QoL of people experiencing TB/HIV coinfection, published in Portuguese, English and Spanish and available in full text. The exclusion criteria were: studies that addressed specific populations, such as people under 18 years old, with psychiatric alterations, people living in street situation or deprived of their freedom.

This research analyzed the study designs, the number of participants evaluated, and the evidence level for each article. Publications without time restrictions were included and found in the Excerpta Medica data BASE (Embase) and Latin American and Caribbean Literature on Health Sciences (LILACS), as well as in the U.S. National Library of Medicine (PubMed) and The Cochrane Library (Cochrane) portals, between March and April 2020. The primary descriptors used were "HIV" AND "Tuberculosis" AND "Quality of Life." Titles and summaries were analyzed to verify those that fit the inclusion criteria. After this stage, the study obtained the complete publications of the selected articles.

The articles were classified according to the levels of scientific evidence, based on the model proposed by Melnyk and FineoutOverholt ${ }^{(12)}$ : I - Evidence derived from at least one well-designed randomized controlled clinical trial; II - Evidence obtained from well-designed clinical trials without randomization; III - Evidence derived from well-designed cohort and case-control studies; IV - Evidence derived from a systematic review of descriptive and qualitative studies; $\mathrm{V}$ - Evidence derived from a single descriptive or qualitative study; $\mathrm{VI}$ - Evidence derived from authorities opinion and/or expert committee report.

Afterward, there was the formation of hierarchical categories according to the methodological design of each study.

\section{RESULTS}

Figure 1 demonstrates the search of the articles in the databases and other sources. 


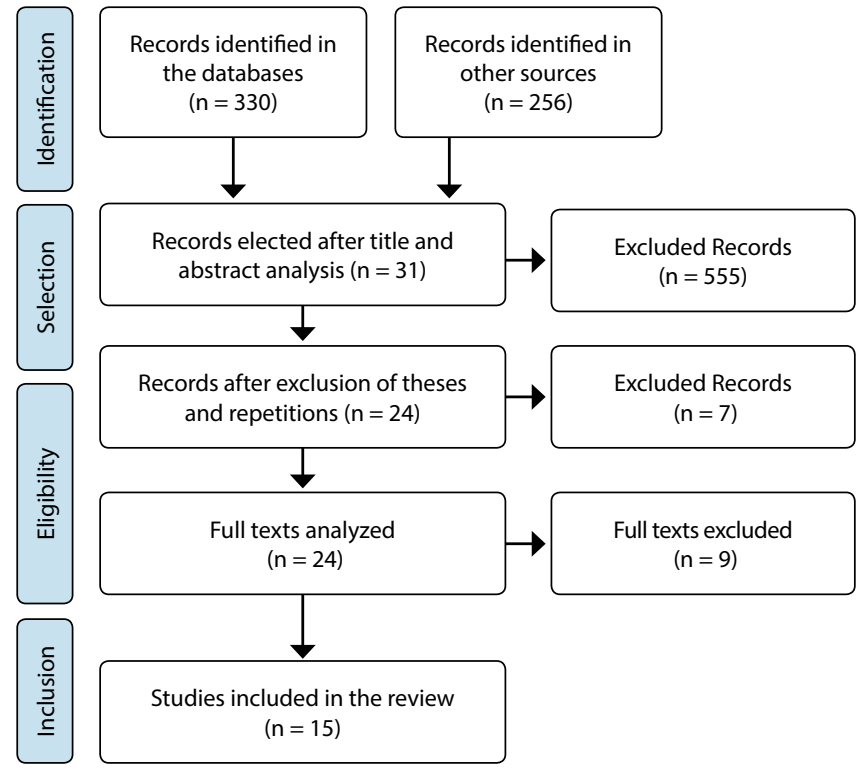

Figure 1 - Selection of studies following PRISMA recommendations ${ }^{(10)}$
A summary of the articles included in the review is demonstrated in Table 1, presented in ascending chronological order according to the title, year of publication, country of study, method, number of participants, evaluation tool, main results, conclusion, and level of evidence.

The 15 selected articles were published between 2009 and 2019 , being two publications in 2009 ${ }^{(13-14)}$, four in 2012 $2^{(7-8,15-16)}$, three in $2013^{(17,19)}$, one in $2014^{(20)}$, one in $2015^{(21)}$, one in $2016^{(22)}$, two in $2018^{(23-24)}$ and one in $2019^{(25)}$. As for the journal, the articles have been published in 13 different ones, with emphasis on Health and Quality of Life Outcomes ${ }^{(14,16)}$ and The International Journal of Tuberculosis and Lung Disease $(19,20)$, with two publications each. Five publications from Brazil ${ }^{(7-8,13,19,24)}$, India ${ }^{(18,20,25)}$, South Africa ${ }^{(16,22)}$ and Ethiopia ${ }^{(14,17)}$, with two publications in each country, and $\mathrm{Ne}-$ pal $^{(21)}$, Nigeria ${ }^{(23)}$ and Thailand ${ }^{(15)}$, with one publication each. Out of the total number of studies, most $(n=14)$ of the publications were in English, two ${ }^{(7-8)}$ had variations for Portuguese, and one for Spanish ${ }^{(24)}$, and another one was exclusively in Portuguese ${ }^{(13)}$.

The following are the main findings, according to the most important themes.

Chart 1 - Characterization of the studies included in the review

\begin{tabular}{|c|c|c|c|c|}
\hline $\begin{array}{c}\text { Title / } \\
\text { Level of evidence }\end{array}$ & $\begin{array}{c}\text { Year/ } \\
\text { Country }\end{array}$ & $\begin{array}{c}\text { Method/Number of } \\
\text { participants/Evaluation } \\
\text { instrument }\end{array}$ & Main results & Conclusion \\
\hline $\begin{array}{l}\text { Coinfection HIV/tuberculosis } \\
\text { (Pott's disease): a case } \\
\text { study }{ }^{(13)} \\
\text { v }\end{array}$ & $\begin{array}{l}2009 \\
\text { Brazil }\end{array}$ & $\begin{array}{l}\text { Case study } \\
\mathrm{n}=1 \text { with TB/HIV } \\
\text { coinfection } \\
\text { Did not use an instrument }\end{array}$ & $\begin{array}{l}\text { Non-adherence to treatment, or } \\
\text { abandonment, of TB and HIV is one of the } \\
\text { significant coinfection problems, resulting } \\
\text { in a decrease in QoL due to therapeutic } \\
\text { failures and resistance to the drugs used. } \\
\text { The non-acceptance of diagnoses, the } \\
\text { socioeconomic level, low schooling, and } \\
\text { prejudice are intimately related to this } \\
\text { problem. }\end{array}$ & $\begin{array}{l}\text { The interaction between HIV and TB } \\
\text { increased morbidity and mortality, } \\
\text { resulting in lower perceived QoL. }\end{array}$ \\
\hline $\begin{array}{l}\text { Tuberculosis and HIV } \\
\text { coinfection: its impact on } \\
\text { quality of life } \mathrm{e}^{(14)} \\
\text { v }\end{array}$ & $\begin{array}{c}2009 \\
\text { Ethiopia }\end{array}$ & $\begin{array}{l}\text { Cross-sectional study } \\
\mathrm{n}=124 \text { with TB/HIV } \\
\text { coinfection and } 467 \text { with } \\
\text { HIV } \\
\text { HOQoL-HIV and Kessler-10 }\end{array}$ & $\begin{array}{l}\text { Patients with TB/HIV coinfection showed } \\
\text { lower QoL in all domains when compared } \\
\text { to HIV-infected without TB. Not having } \\
\text { depression, having an income source, and } \\
\text { family support were strongly associated } \\
\text { with most QoL domains. In patients with } \\
\text { both diseases, those who had depression } \\
\text { were } 8.8 \text { times more likely to have physical } \\
\text { health problems. }\end{array}$ & $\begin{array}{l}\text { The TB control program should develop } \\
\text { strategies to improve the QoL of people } \\
\text { with TB/HIV coinfections. Depression } \\
\text { and self-stigma/self-disapproval should } \\
\text { be the targets for intervention to } \\
\text { improve QoL. }\end{array}$ \\
\hline $\begin{array}{l}\text { Aids and tuberculosis: } \\
\text { coinfection from the } \\
\text { perspective of the patients' } \\
\text { quality of life }{ }^{(7)} \\
\text { V }\end{array}$ & $\begin{array}{l}2012 \\
\text { Brazil }\end{array}$ & $\begin{array}{l}\text { Cross-sectional study } \\
\mathrm{n}=57 \text { with TB/HIV } \\
\text { coinfection and } 58 \text { with } \\
\text { HIV } \\
\text { WHOQoL-HIV Bref }\end{array}$ & $\begin{array}{l}\text { In the evaluation of QoL, those who } \\
\text { experienced coinfection presented inferior } \\
\text { results in all domains, with a significant } \\
\text { difference in the Physical, Psychological, } \\
\text { Level of Independence, and Social } \\
\text { Relations domains. }\end{array}$ & $\begin{array}{l}\text { It is necessary to develop joint } \\
\text { policy strategies to reduce the } \\
\text { epidemiological impact of one disease } \\
\text { on another, such as early detection, } \\
\text { implementation of ART, investigation } \\
\text { of TB in people with HIV, treatment } \\
\text { of latent TB, expansion of DOT, and } \\
\text { training of professionals, enabling } \\
\text { increased QoL for those affected by } \\
\text { coinfection. }\end{array}$ \\
\hline $\begin{array}{l}\text { Health-related quality of } \\
\text { life among patients with } \\
\text { tuberculosis and HIV in } \\
\text { Thailand }{ }^{(15)} \\
\text { v }\end{array}$ & $\begin{array}{c}2012 \\
\text { Thailand }\end{array}$ & $\begin{array}{l}\text { Cross-sectional study } \\
\mathrm{n}=222 \text { with TB/HIV } \\
\text { coinfection } \\
\text { Structured questionnaire; } \\
\text { EuroQol (EQ-5D); EuroQol } \\
\text { Visual Analog Scale (EQ- } \\
\text { VAS) }\end{array}$ & $\begin{array}{l}\text { The QoL score was higher among patients } \\
\text { cured of TB; and lower for those in } \\
\text { treatment of pharmaco-resistant TB. }\end{array}$ & $\begin{array}{l}\text { The treatments for TB and the resistant } \\
\text { form negatively impacted the patients' } \\
\text { self-perceived health status, but this } \\
\text { effect diminished after the successful } \\
\text { treatment. There is a need for research } \\
\text { that presents strategies to improve QoL } \\
\text { in such conditions. }\end{array}$ \\
\hline
\end{tabular}


Chart 1

\begin{tabular}{|c|c|c|c|c|}
\hline $\begin{array}{c}\text { Title / } \\
\text { Level of evidence }\end{array}$ & $\begin{array}{c}\text { Year/ } \\
\text { Country }\end{array}$ & $\begin{array}{c}\text { Method/Number of } \\
\text { participants/Evaluation } \\
\text { instrument }\end{array}$ & Main results & Conclusion \\
\hline $\begin{array}{l}\text { Quality of life among } \\
\text { tuberculosis (TB), TB } \\
\text { retreatment and/or TB-HIV } \\
\text { coinfected primary public } \\
\text { health care patients in three } \\
\text { districts in South Africa }{ }^{(16)} \\
\qquad \mathbf{v}\end{array}$ & $\begin{array}{l}2012 \\
\text { South } \\
\text { Africa }\end{array}$ & $\begin{array}{l}\text { Cross-sectional study } \\
\mathrm{n}=2,935 \text { with TB/HIV } \\
\text { coinfection and 1,965 with } \\
\text { tuberculosis } \\
\text { Kessler-10; AUDIT; Two } \\
\text { alternative questions; } \\
\text { Social Functioning } 12\end{array}$ & $\begin{array}{l}\text { Positive effects for QoL were found in } \\
\text { the domains of mental health, emotional } \\
\text { role, energy and fatigue, social function, } \\
\text { and physical role, while adverse effects } \\
\text { were observed on general health, body } \\
\text { pain, and physical function. Higher } \\
\text { schooling, less psychological suffering, less } \\
\text { chronic conditions, less poverty, and low } \\
\text { psychological suffering had positive effects } \\
\text { on QoL. }\end{array}$ & $\begin{array}{l}\text { TB and HIV have weakened patients' } \\
\text { physical capacity and damaged QoL, } \\
\text { soTB control programs must develop } \\
\text { strategies to improve the QoL of } \\
\text { patients who experience coinfection. }\end{array}$ \\
\hline $\begin{array}{l}\text { Quality of life aspects } \\
\text { of patients with HIV/ } \\
\text { tuberculosis coinfection } \\
\text { V }\end{array}$ & $\begin{array}{l}2012 \\
\text { Brazil }\end{array}$ & $\begin{array}{l}\text { Cross-sectional } \\
\text { study, qualitative and } \\
\text { quantitative } \\
\mathrm{n}=34 \text { with TB/HIV } \\
\text { coinfection } \\
\text { HAT-QoL }\end{array}$ & $\begin{array}{l}\text { QoL has shown itself impaired in areas } \\
\text { related to economic, sexual, and diagnostic } \\
\text { confidentiality issues. It was also evidenced } \\
\text { that coinfection imposes changes in daily } \\
\text { life that potentiated the commitment of } \\
\text { QoL. }\end{array}$ & $\begin{array}{l}\text { Experiencing coinfection has } \\
\text { negatively influenced QoL. Health- } \\
\text { promoting interventions could } \\
\text { mitigate repercussions. }\end{array}$ \\
\hline $\begin{array}{l}\text { Change in quality of life: } \\
\text { a follow up study among } \\
\text { patients with HIV infection } \\
\text { with and without TB in } \\
\text { Ethiopia }^{(17)} \\
\quad \text { III }\end{array}$ & $\begin{array}{c}2013 \\
\text { Ethiopia }\end{array}$ & $\begin{array}{l}\text { Observational } \\
\mathrm{n}=97 \text { with TB/HIV } \\
\text { coinfection and } 455 \text { with } \\
\text { HIV } \\
\text { WHOQoL-HIVBref; } \\
\text { Kessler-10. }\end{array}$ & $\begin{array}{l}\text { There was an improvement in physical, } \\
\text { psychological, social, environmental, and } \\
\text { spiritual QoL throughout the treatment, } \\
\text { and it was more remarkable in all } \\
\text { dimensions for those who experienced } \\
\text { coinfection. The severe mental disorder } \\
\text { was associated with worse QoL. }\end{array}$ & $\begin{array}{l}\text { ART and TB treatment have improved } \\
\text { QoL, particularly among patients } \\
\text { experiencing coinfection. The } \\
\text { recommendation is to integrate mental } \\
\text { health services with TB/HIV programs } \\
\text { and training of caregivers to identify } \\
\text { and treat common mental disorders in } \\
\text { due course and improve QoL. }\end{array}$ \\
\hline $\begin{array}{l}\text { 'I cry every day': experiences } \\
\text { of patients coinfected with } \\
\text { HIV and multidrug-resistant } \\
\text { tuberculosis }{ }^{(18)} \\
\qquad \mathbf{V}\end{array}$ & $\begin{array}{l}2013 \\
\text { India }\end{array}$ & $\begin{array}{l}\text { Qualitative } \\
\mathrm{n}=12 \text { with } \\
\text { multipharmaresistant } \\
\text { TB/HIV coinfection, } 5 \text { lay } \\
\text { caregivers, } 10 \text { healthcare } \\
\text { professionals } \\
\text { Did not use an instrument }\end{array}$ & $\begin{array}{l}\text { The side effects of the medications were } \\
\text { considered seriously debilitating. Family } \\
\text { caregivers are crucial to maintaining } \\
\text { patients' mental and physical health, but } \\
\text { they also report high fatigue and stress } \\
\text { levels. Health professionals stated that the } \\
\text { barriers to treatment compliance were } \\
\text { fundamentally social, not medical and } \\
\text { that they felt powerless in the face of this } \\
\text { situation. }\end{array}$ & $\begin{array}{l}\text { The treatment of pharmaco-resistant } \\
\text { TB in PLWHAs requires the dedication } \\
\text { of patients, caregivers, and family. } \\
\text { Treatments consume many resources } \\
\text { and can negatively affect QoL, so they } \\
\text { require high levels of support from } \\
\text { family and caregivers to encourage } \\
\text { patient compliance and retention. }\end{array}$ \\
\hline $\begin{array}{l}\text { Quality of life among people } \\
\text { treated for tuberculosis and } \\
\text { human immunodeficiency } \\
\text { virus in Rio de Janeiro, } \\
\text { Brazil(19) } \\
\qquad \text { V }\end{array}$ & $\begin{array}{l}2013 \\
\text { Brazil }\end{array}$ & $\begin{array}{l}\text { Cross-sectional study } \\
\mathrm{n}=9 \text { with TB/HIV } \\
\text { coinfection, } 45 \text { with HIV } \\
\text { and } 44 \text { with TB } \\
\text { MOS-HIV and VAS (visual } \\
\text { analogic scale) }\end{array}$ & $\begin{array}{l}\text { Participants with TB/HIV coinfection } \\
\text { reported less physical health than } \\
\text { participants with TB or HIV alone, but } \\
\text { there was no difference in mental health. } \\
\text { Participants who had TB or HIV separately } \\
\text { did not differ regarding QoL or mental } \\
\text { health, but TB was associated with worse } \\
\text { physical health. }\end{array}$ & $\begin{array}{l}\text { There are similar decreases in QoL } \\
\text { in participants undergoing HIV and } \\
\text { TB treatment with no evidence of an } \\
\text { additive effect in participants with TB/ } \\
\text { HIV coinfection. }\end{array}$ \\
\hline $\begin{array}{l}\text { 'I'm fed up': experiences } \\
\text { of prior anti- } \\
\text { tuberculosis treatment } \\
\text { in patients with drug- } \\
\text { resistant tuberculosis and } \\
\text { HIV(20) } \\
\text { V }\end{array}$ & $\begin{array}{l}2014 \\
\text { India }\end{array}$ & $\begin{array}{l}\text { Qualitative } \\
\mathrm{n}=12 \text { with coinfection } \\
\text { Pharmacorresistant TB/HIV } \\
\text { Did not use an instrument }\end{array}$ & $\begin{array}{l}\text { The study participants reported long } \\
\text { therapeutic itineraries related to the } \\
\text { diagnostic procedures and the treatment } \\
\text { period, leading to fatigue. They also } \\
\text { expressed concern about the lack of } \\
\text { effectiveness of the treatment, based on } \\
\text { past experiences. }\end{array}$ & $\begin{array}{l}\text { Participants reported negative } \\
\text { experiences with previous treatments } \\
\text { for HIV and TB, which affected } \\
\text { perceived QoL. Diagnosis and initiation } \\
\text { of treatments in a quick and timely } \\
\text { manner, coupled with a patient- } \\
\text { centered support system, could help } \\
\text { raise the credibility of the treatments. }\end{array}$ \\
\hline $\begin{array}{l}\text { Assessing Quality of Life } \\
\text { and Depression Among } \\
\text { People Living With HIV/AIDS } \\
\text { and TB-HIV coinfection in } \\
\text { Kathmandu, Nepal(21) } \\
\qquad \mathbf{v}\end{array}$ & $\begin{array}{l}2015 \\
\text { Nepal }\end{array}$ & $\begin{array}{l}\text { Cross-sectional study } \\
\mathrm{n}=71 \text { with TB/HIV } \\
\text { coinfection and } 75 \text { with HIV } \\
\text { WHOQoL-HIV, Beck } \\
\text { Depression Inventory Scale. }\end{array}$ & $\begin{array}{l}\text { Participants with TB/HIV coinfection } \\
\text { had low QoL, and depression was more } \\
\text { frequent than HIV-infected participants. } \\
\text { CD4 cell count, educational status, } \\
\text { occupation, ethnicity, family size, and } \\
\text { depression were factors related to QoL. }\end{array}$ & $\begin{array}{l}\text { TB control programs should develop } \\
\text { strategies to improve the QoL of people } \\
\text { with coinfection, just as there should be } \\
\text { interventions aimed at depression to } \\
\text { improve the QoL of people living with } \\
\text { HIV, with or without TB. }\end{array}$ \\
\hline $\begin{array}{l}\text { Longitudinal assessment of } \\
\text { the health-related quality of } \\
\text { life of HIV infected patients } \\
\text { treated for tuberculosis } \\
\text { and HIV in a high burden } \\
\text { setting } \\
\qquad \text { III }\end{array}$ & $\begin{array}{l}2016 \\
\text { South } \\
\text { Africa }\end{array}$ & $\begin{array}{l}\text { Observational } \\
n=76 \text { with TB/HIV } \\
\text { coinfection } \\
\text { HRQoL }\end{array}$ & $\begin{array}{l}\text { There was a significant increase in the total } \\
\text { score in both groups with the months' } \\
\text { passing, considering mainly the CD4 cell } \\
\text { elevation. There was no difference in scores } \\
\text { between participants who underwent ART } \\
\text { and TB treatment and those who received } \\
\text { only TB treatment. Less adverse respiratory } \\
\text { events were positively related to better QoL. }\end{array}$ & $\begin{array}{l}\text { There was improvement in QoL related } \\
\text { to the decrease of adverse events and } \\
\text { signs and symptoms of TB. Lower QoL } \\
\text { was related to the number and type of } \\
\text { adverse events although there was a } \\
\text { cure of TB. }\end{array}$ \\
\hline
\end{tabular}




\begin{tabular}{|c|c|c|c|c|}
\hline $\begin{array}{c}\text { Title / } \\
\text { Level of evidence }\end{array}$ & $\begin{array}{c}\text { Year/ } \\
\text { Country }\end{array}$ & $\begin{array}{l}\text { Method/Number of } \\
\text { participants/Evaluation } \\
\text { instrument }\end{array}$ & Main results & Conclusion \\
\hline $\begin{array}{l}\text { Health-related quality of } \\
\text { life of HIV patients with } \\
\text { and without tuberculosis } \\
\text { registered in a Tertiary } \\
\text { Hospital in Port Harcourt, } \\
\text { Nigeria }^{(23)} \\
\text { v }\end{array}$ & $\begin{array}{c}2018 \\
\text { Nigeria }\end{array}$ & $\begin{array}{l}\text { Cross-sectional study } \\
n=144 \text { with TB/HIV } \\
\text { coinfection and } 144 \text { with } \\
\text { HIV } \\
\text { WHOQoL-HIV }\end{array}$ & $\begin{array}{l}\text { Patients who experienced coinfection had } \\
\text { lower QoL in the physical, psychological, } \\
\text { and global domains than patients with HIV. } \\
\text { The two groups did not differ significantly } \\
\text { in the Social and Environmental domains. }\end{array}$ & $\begin{array}{l}\text { The TB/HIV condition has significantly } \\
\text { reduced QoL; therefore, attention } \\
\text { should be focused on managing the } \\
\text { physical and mental health of patients } \\
\text { experiencing coinfection in order to } \\
\text { improve QoL. }\end{array}$ \\
\hline $\begin{array}{l}\text { Social support and quality } \\
\text { of life of people with } \\
\text { tuberculosis/HIV(24) } \\
\text { V }\end{array}$ & $\begin{array}{l}2018 \\
\text { Brazil }\end{array}$ & $\begin{array}{l}\text { Cross-sectional study } \\
\mathrm{n}=57 \text { with TB/HIV } \\
\text { coinfection } \\
\text { WHOQoL-HIV Bref; Escala } \\
\text { de Apoio Social para } \\
\text { Pessoas Vivendo com HIV/ } \\
\text { AIDS; e questionário. }\end{array}$ & $\begin{array}{l}\text { Positive associations were found between } \\
\text { social support and QoL, and a relationship } \\
\text { was identified between instrumental } \\
\text { support and the Physical and Social } \\
\text { Relations domains. Emotional support was } \\
\text { related to all domains except Spirituality. }\end{array}$ & $\begin{array}{l}\text { Clinical manifestations and fear } \\
\text { of stigma have affected social } \\
\text { relationships of people who experience } \\
\text { TB/HIV coinfection, causing a negative } \\
\text { impact on QoL; in contrast, support } \\
\text { from family, friends and health } \\
\text { professionals has increased self-esteem } \\
\text { and adherence to treatment, acting } \\
\text { positively in QoL. }\end{array}$ \\
\hline $\begin{array}{l}\text { Quality of life among HIV- } \\
\text { tuberculosis coinfected } \\
\text { patients }^{(25)} \\
\text { V }\end{array}$ & $\begin{array}{l}2019 \\
\text { India }\end{array}$ & $\begin{array}{l}\text { Cross-sectional study } \\
\mathrm{n}=26 \text { with TB/HIV } \\
\text { coinfection and } 78 \text { with } \\
\text { HIV } \\
\text { WHOQoL-HIV; Beck } \\
\text { Depression Inventory } \\
\text { Scale. }\end{array}$ & $\begin{array}{l}\text { Participants with TB/HIV coinfection scored } \\
\text { lower in all domains than participants who } \\
\text { experienced HIV exclusively, suggesting } \\
\text { that patients with coinfection have a lower } \\
\text { QoL. }\end{array}$ & $\begin{array}{l}\text { It is imperative to identify the } \\
\text { determinants and work for improved } \\
\text { QoL of people living with HIV. }\end{array}$ \\
\hline
\end{tabular}

Note: TB - Tuberculosis; QoL - Quality of Life; ART - Antiretroviral Treatment; DOT - Directly Observed Treatment; PLWHA - People Living with HIV/Aids.

\section{Types of studies}

Ten studies were cross-sectional studies ${ }^{(7-8,14-16,19-21,23-25)}$; two qualitative ${ }^{(18,20)}$; two observational ${ }^{(17-22)}$; one cross-sectional studyqualitative ${ }^{(8)}$; and one case study ${ }^{(13)}$. The predominance of studies with a quantitative approach is evident, and only three employed a qualitative method ${ }^{(8,18,20)}$.

\section{Instruments applied}

It was observed that a variety of instruments were used for the QoL evaluation, with evidence from the WHO Quality of Life Instrument for people with HIV, in the extended version (WHOQoLHIV) $)^{(14,21,23,25)}$ and abbreviated (WHOQoL-HIV Bref) $)^{(7,17,24)}$, in seven studies. In the sequence, the Kessler-10 psychological stress scale was used in three studies ${ }^{(14,16-17)}$, the Beck Depression Inventory Scale in two ${ }^{(21,25)}$. The HRQoL ${ }^{(22)}$, and EuroQoL ${ }^{(15)}$, AUDIT $^{(16)}$, Social Functioning ${ }^{(16)}$, Hat-QoL ${ }^{(8)}$, Social Support Scale for People Living with HIV/AIDS ${ }^{(24)}$, MOS-HIV(19), and VAS (visual analogic scale) ${ }^{(19)}$ were employed only once. We highlight the use of more than

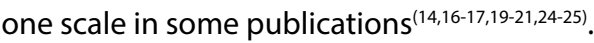

\section{Interventions to improve Quality of Life}

The articles have demonstrated that TB/HIV coinfection can compromise QoL more than experiencing one of the diseas$\mathrm{es}^{(7,14,17,23)}$. It is emphasized the importance of developing and improving programs and policies for screening and managing both infections $s^{(7,14,16,24)}$ and suggested focusing on some actions, such as improving early detection of HIV and TB, implementing $A R T$, investigating TB in seropositive individuals, treating latent TB, and expanding Directly Observed Treatment (DOT).
Moreover, there were suggested interventions focused on mental health working with self-stigma issues, i.e., self-disapproval and depression, and it was recommended the integration of mental health services with TB/HIV programs. There should be training for professional caregivers to immediately identify and treat common mental disorders, therefore improving the QoL of people experiencing TB/HIV coinfection ${ }^{(7,17,23)}$

The articles pointed out the need for psychological support to this group that is emotionally fragile and vulnerable to mental disorders and other diseases ${ }^{(7,17,23)}$. They have also shown that further research is needed to know better the QoL of this specific group ${ }^{(14-15,17,23)}$.

\section{Factors related to decline or improving quality of life}

There were listed as contributors to a better QoL in this population: source of income, higher education, family, and social support, as well as successful treatment of TB and ART ${ }^{(14-16,24)}$.

As for barriers to improving QoL, it was highlighted the association with chronic diseases, poverty, psychic suffering, depression, severe mental disorders, self-stigma/self-disapproval, treatment of $T B$, and pharmaco-resistant TB due to the several side effects ${ }^{(14,17)}$.

\section{DISCUSSION}

The national and international literature presented studies related to PLWHA ${ }^{(26-29)}$ and people living with $\mathrm{TB}^{(6,30-32)}$ separately.

In this review, there was a lack of temporal regularity in the studies published, with greater concentration in 2012. The low number of publications each year may suggest a lack of interest in the topic in question.

It is known that TB is a socially determined disease, and its occurrence is related to precarious living conditions. This review's 
studies were conducted in underdeveloped or developing countries, which host cases that show TB/HIV coinfection.

It should be highlighted that 10 out of 15 articles included in the review are cross-sectional studies, showing, besides the low amount of publications on the subject, that the studies present a low level of evidence, considering that cross-sectional research occupies level $\mathrm{V}^{(12)}$. Thus, besides the need to develop studies on QoL of people who experience TB/HIV coinfection, it is fundamental to advance those studies with a higher level of reliability, which exposes scientific evidence on the subject. The scope of understanding QoL can be in other types of methods than cross-sectional studies, and there is a demand for studies that synthesize other parameters not achieved so far.

Another significant fact to discuss is the predominance of quantitative methodology, demonstrating that it is necessary to develop investigations with a qualitative approach in order to reveal the meanings and perceptions of coinfection for the people affected, something to be better understood with studies that make it possible to give voice to this group.

The articles included in the review appropriated the definition of QoL proposed by $\mathrm{WHO}^{(5)}$, which transcends the physical aspects, by addressing the importance of psychic and social aspects for maintaining QoL. These studies demonstrated how the experience of living with a coinfection might impact the mental health of these people, and it is necessary to articulate services in this field of practices and knowledge with HIV and TB referral and treatment centers.

The articles' synthesis showed that the treatment of both TB and HIV is fundamental for the cure of TB and maintenance of QoL. However, the low adherence to treatment represented an impediment to the control of the disease. The studies showed that the participants and their families experienced the impact of the diagnosis with feelings of hopelessness and disillusionment associated with medication's side effects. The treatments themselves represent factors associated with the impairment of QoL; consequently, there is a need for investment in the production of new drugs that minimize side effects and require lesser time to complete TB treatment and increase treatment adherence and QoL.

The studies revealed the need to deepen knowledge on the influence of social determinants of health in people living with TB/HIV coinfection. The articles have convergent results, showing that experiencing coinfection resulted in a greater decrease in QoL than experiencing HIV or TB alone, but the same studies showed that QoL suffered an equally significant influence when associated with poverty, chronic diseases, mental suffering, lower income, schooling, as well as social and family support.

The association of TB with HIV poses challenges, mainly related to treatment adherence. There has also been a variable geographical distribution of studies mostly concentrated in developing countries. Social issues have been the major impediments to raising $\mathrm{QoL}$, so it is necessary to transform living conditions and access to health services and disseminate knowledge about such diseases in a way that makes sense to individuals' daily lives. It requires the strengthening of public social support policies to provide essential resources - such as food, housing, transportation, security, and education - to the vast majority of the population who faces these diseases.

The results showed little scientific production on the subject. The lack of standardization regarding the evaluation tool and the standardization of QoL evaluation of people with TB/HIV coinfection, on the one hand, makes more complex the evaluation of QoL propitiating needs, which allows the development of a healthy daily life. However, it is necessary to consider that, not rarely, closed instruments, which do not allow the assumption of more personal issues and which reveal the wear and tear and strengthening for the conduct of life, can limit the understanding of the process of health-disease and its repercussions on the daily routine.

Also, such instruments need to provide a broad view, of a multiprofessional and interdisciplinary order, coherent with the concept of QoL, to instrumentalize the work of health professionals in order to rethink the multiple constitutive sides of QoL, which is permeated by cultural, political, and social processes, transcending the approach that restricts its understanding to the volitive and individual component.

\section{Study limitations}

The search strategy may have been limited, given the possibility that publications in local databases were not included in this review, which may have generated a bias.

\section{Contributions to the Fields of Nursing, Health or Public Policy}

This review highlights the need for investigations on QoL of people experiencing TB/HIV coinfection. The studies demonstrated that both diseases primarily affect participants who are victims of social exclusion or who have vulnerabilities of both an individual and a social nature, such as low socioeconomic and schooling levels, as well as those related to access to services, which makes up the programmatic dimension of the concept of Vulnerability.

Among a series of other duties, the nurse's fundamental participation in the prevention and control of TB and HIV stands out and the promotion of actions that support the improvement of QoL of people living with such diseases. From a perspective that makes it possible to recognize health needs and provide answers for the improvement of QoL, the health team can lead to overcoming the weaknesses and difficulties experienced by these people.

\section{CONCLUSIONS}

The selected publications present a low level of scientific evidence. This review highlighted the variability of instruments used to analyze and evaluate QoL, limiting the understanding of the processes experienced by people with such diseases, indicating that this is an area of knowledge that needs further investigation.

Also, qualitative research can bring contributions by enabling people with coinfection to share needs and difficulties of living the health-disease process, including the perception about QoL. It allows the development of strategies to improve the prevention and control of both diseases and promote the physical, mental, and social health of this population group.

\section{FUNDING}

We would like to thank the São Paulo Research Foundation (FAPESP), for granting scholarship for scientific initiation. 


\section{REFERENCES}

1. World Health Organization (WHO). Global Tuberculosis Report 2020 [Internet]. Geneva: WHO; 2020 [cited 2020 Oct 17]. Available from: https://apps.who.int/iris/bitstream/handle/10665/336069/9789240013131-eng.pdf?ua=1

2. Ministério da Saúde (BR). Secretaria de Vigilância em Saúde. Boletim Tuberculose 2020 [Internet]. 2020[cited 2020 Oct 03]. Available from: https://www.saude.gov.br/images/pdf/2020/marco/24/Boletim-tuberculose-2020-marcas--1-.pdf

3. Ministério da Saúde (BR). Secretaria de Vigilância em Saúde. Departamento de Vigilância, Prevenção e Controle das Infecções Sexualmente Transmissíveis, do HIV/Aids e das hepatites Virais. Protocolo clínico e diretrizes terapêuticas para manejo da infecção pelo HIV em adultos[Internet]. Brasília: MS; 2018 [cited 2020 Jul 31]. Available from: http://www.aids.gov.br/pt-br/pub/2013/ protocolo-clinico-e-diretrizes-terapeuticas-para-manejo-da-infeccao-pelo-hiv-em-adultos

4. Silva JB, Cardoso GCP, Netto AR, Kritski AL. Os significados da comorbidade para os pacientes vivendo com TB/HIV: repercussões no tratamento. Physis Rev Saúde Colet 2015;25(1): 209-29. https://doi.org/10.1590/S0103-7331201500010001

5. World Health Organization (WHO). Country protocol for developing the WHO quality of life (WHOQOL): HIV/aids module [Internet]. Genebra:WHO; 1997 [cited 2020 Jul 31]. Available from: https://www.who.int/mental_health/media/68.pdf

6. Kastien-Hilka T, Rosenkranz B, Sinanovic E, Bennett B, Schwenkglenks M. Health-related quality of life in South African patients with pulmonary tuberculosis. PLOS ONE 2017;12(4). https://doi.org/10.1371/journal.pone.0174605

7. Neves LAS, Canini SR, Reis RK, Santos CB, Gir E. Aids and tuberculosis: coinfection from the perspective of the quality of life of patients. Rev Esc Enferm USP. 2012;46(3):704-10. https://doi.org/10.1590/S0080-62342012000300024

8. Lemos LA, Feijão AR, Gir E, Galvão MTG. Quality of life aspects of patients with HIV/tuberculosis co-infection. Acta Paul Enferm. 2012;25(sple):41-7. https://doi.org/10.1590/S0103-21002012000800007

9. Peters MDJ, Godfrey CM, Khalil HB, McInerney P, Parker D, Soares CB. Guidance for conducting systematic scoping reviews. Int J EvidenceBased Healthcare. 2015;13(3):141-6. https://doi.org/10.1097/XEB.0000000000000050

10. Tricco AC, Lillie E, Zarin W, O'Brien KK, Colquhoun H, Levac D, et al. PRISMA Extension for Scoping Reviews (PRISMA-ScR): checklist and explanation. Ann Intern Med. 2018;169(7):467-73. https://doi.org/10.7326/M18-0850

11. Santos CMS, Pimenta CAM, Nobre MRC. A estratégia PICO para a construção da pergunta de pesquisa e busca de evidências. Rev Latino-Am Enfermagem. 2007;15(3):508-11. https://doi.org/10.1590/S0104-11692007000300023

12. Melnyk BM, Fineout-Overholt E. Making the case for evidence based practice In: Evidence based practice in nursing \& healthcare: a guide to best practice. Philadelphia: Lippincott Williams \& Wilkins. 2005. p.239- 344.

13. Ribeiro KCS, Lima KMSR, Loureiro AD. Coinfection HIV/tuberculosis (Pott's disease): a case study. DST J Bras Doenças Sex Transm [Internet]. 2009 [cited 2020 Jul 30];21(2):83-6. Available from: http://www.dst.uff.br/revista21-2-2009/7\%20-\%20Coinfeccao\%20HIV-tuberculose.pdf

14. Deribew A, Tesfaye M, Hailmichael Y, Negussu N, Daba S, Wogi A, et al. Tuberculosis and HIV co-infection: its impact on quality of life. Health Qual Life Outcomes. 2009;7:105. https://doi.org/10.1186/1477-7525-7-105

15. Kittikraisak W, Kingkaew P, Teerawattananon Y, Yothasamut J, Natesuwan S, Manosuthi W, et al. Health related quality of life among patients with tuberculosis and HIV in Thailand. PLoS One. 2012;7(1):e29775. https://doi.org/10.1371/journal.pone.0029775

16. Louw J, Peltzer K, Naidoo P. Matseke G. Mchunu G, Tutshana B. Quality of life among tuberculosis (TB), TB retreatment and/or TB-HIV co-infected primary public health care patients in three districts in South Africa. Health Qual Life Outcomes. 2012;ID77. https://doi. org/10.1186/1477-7525-10-77

17. Deribe A, Deribe K, Reda AA, Tesfaye M, Hailmichael Y, Maja T, et al. Change in quality of life: a follow up study among patients with HIV infection with and without TB in Ethiopia. BMC Public Health. 2013;29;13:408. https://doi.org/10.1186/1471-2458-13-408

18. Isaakidis P, Rangan S, Pradhan A, Ladomirska J, Reid T, Kielmann K. 'I cry every day': experiences of patients co-infected with HIV and multidrug-resistant tuberculosis. Trop Med Int Health. 2013;18(9):1128-33. https://doi.org/10.1111/tmi.12146

19. Dowdy DW, Israel G, Vellozo V, Saraceni V, Cohn S, Cavalcante S, et al. Quality of life among people treated for tuberculosis and human immunodeficiency virus in Rio de Janeiro, Brazil. Int J Tuberc Lung Dis. 2013;17(3):345-7. https://doi.org/10.5588/ijtld.12.0123

20. Furin J, Isaakidis P, Reid AJ, Kielmann K. 'I'm fed up': experiences of prior anti-tuberculosis treatment in patients with drug-resistant tuberculosis and HIV. Int J Tuberc Lung Dis. 2014;18(12):1479-84. https://doi.org/10.5588/ijtld.14.0277

21. Timilsina S, Regmi, K. Assessing quality of life and depression among people living with HIV/AIDS and TB-HIV Coinfection in Kathmandu, Nepal. SAARC J Tuberc, Lung Dis HIV/AIDS. 2015;10(3126). https://doi.org/10.3126/saarctb.v11i2.12428

22. Mthiyane T, Pym A, Dheda K, Rustomjee R, Reddy T, Manie S. Longitudinal assessment of health related quality of life of HIV infected patients treated for tuberculosis and HIV in a high burden setting. Qual Life Res. 2016;25(12):3067-76. https://doi.org/10.1007/s11136-016-1332-4

23. Kanu NE, Tobin-West Cl. Health-related quality of life of HIV patients with and without tuberculosis registered in a Tertiary Hospital in Port Harcourt, Nigeria. HIV AIDS Rev. 2018;17:3(210-17). https://doi.org/10.5114/hivar.2018.78494

24. Neves LAS, Castreghinic C, Reis RK, Canini SEM, Gir E. Social support and quality of life of people with tuberculosis/HIV. Enferm Glob. 2018;50:1-5. https://doi.org/10.6018/eglobal.17.2.276351 
25. Jha DK, Jha J, Jha AK, Achappa B, Holla R. Quality of life among HIV-tuberculosis co-infected patients. Perspect Clin Res. 2019;10(3):125-9. https://doi.org/10.4103/picr.PICR_99_18

26. Jesus GJ. Oliveira LB, Caliari JS, Queiroz AAFL, Gir E, Reis RK. Dificuldades do viver com HIV/Aids: entraves na qualidade de vida. Acta Paul Enferm. 2017;30(3):3017. https://doi.org/10.1590/1982-0194201700046

27. Oliveira FBM, Queiroz AAFLN, Sousa AFL, Moura MEB, Reis RK. Orientação sexual e qualidade de vida de pessoas vivendo com HIV/aids. Rev Bras Enferm. 2017;70(5):1004-10. https://doi.org/10.1590/0034-7167-2016-0420

28. Araújo KMST, Leal MCC, Marques APO, Silva SRA, Aguiar RB, Tavares MTDB. Quality of life evaluation of elderly people with HIV assisted in referral services. Cienc Saúde Coletiva. 2020;25(6):2009-16. https://doi.org/10.1590/1413-81232020256.20512018

29. Dutra BS, Lédo AP, Lins-Kusterer L, Luz E, Prieto IR, Brites C. Changes health-related quality of life in HIV-infected patients following initiation of antiretroviral therapy: a longitudinal study. Braz J Infect Dis. 2019;23(4):211-7. https://doi.org/10.1016/j.bjid.2019.06.005

30. Aggarwal AN. Quality of life with tuberculosis. J Clin Tuberc Other Mycobact Dis. 2019(17):100-21. https://doi.org/10.1016/j. jctube.2019.100121

31. Valadares RMC, Carvalho WDS, Miranda SS. Association of adverse drug reaction to anti-tuberculosis medication with quality of life in patients in a tertiary referral hospital. Rev Soc Bras Med Trop. 2019;(53):20190207. https://doi.org/10.1590/0037-8682-0207-2019

32. Jaber AAS, Ibrahim B. Health-related quality of life of patients with multidrug-resistant tuberculosis in Yemen: prospective study. Health Qual Life Outcomes. 2019;17(1):142. https://doi.org/10.1186/s12955-019-1211-0 